\title{
Progress on the nomenclature of volcanic rocks, carbonatites, melilite-rocks and lamprophyres
}

SIR - A meeting of the I.U.G.S. Subcommission on the Systematics of Igneous Rocks was held in Prague in September 1977. Under the Chairmanship of Professor A. Streckeisen (Berne), and with Dr R. Schmid (Zurich) as Secretary, the following were present: A. Dudek. Prague; S. V. Efremova, Moscow; M. J. Le Bas, Leicester (working group on effusive and pyroclastic rocks); R. W. Le Maitre, Melbourne; P. A. Sabine, London; K. Smulikowski, Warsaw; W. Wimmenauer, Freiburg; B. Zanettin, Padua; and B. N. Church, Vancouver, and A. E. Wright, Birmingham, also attended.

The Recommendations and Suggestions so far agreed will be published in due course with the full text to appear possibly under the auspices of the I.U.G.S.

The principal matters dealt with were as follows:

\section{Principles of classification of volcanic rocks}

For plutonic rocks the Subcommission has agreed and published a classification based on modal mineral content, plotted on a quartz-alkali-feldspar-plagioclase-feldspathoid (foid) double triangle (see, for example, Sabine, 1974; Streckeisen, 1976).

For volcanic rocks, the Subcommission recommends that

(1) If modal mineral contents can be established, volcanic rocks should be classified and named according to their mineral composition, i.e. their position in the QAPF diagram. Other parameters may, where necessary, be used to subdivide fields further.

(2) If modal contents are not available, chemical parameters have to be considered as a basis for a chemical classification which, however, should be correlated with the mineralogical classification, i.e. rocks with known modal contents are given the same name by the chemical classification as by the QAPF diagram. The Subcommission, however, realizes that an exact coincidence between the modal QAPF classification and any chemical classification will rarely occur. Therefore, each chemical classification proposed has to be tested as to its validity.

\section{Root names}

The QAPF diagram (Fig. 1 a) is divided into fields which have root names only. Many special names are not discussed; and many volcanic rock groups need supplementary criteria, notably basalt and andesite.

Field 2. Alkali-feldspar rhyolite. Alkali-rhyolite applies when the rock contains alkali pyroxene or alkali amphibole or both, in mode or norm (similarly for $6^{*}, 6,6^{\prime}$ ).

Field 3. Rhyolite. Rhyodacite may be used for rocks transitional between rhyolite and dacite.

Fields 4 and 5. Dacite. The classical dacites of Transylvania are in field 4.

Field 6*. Quartz-alkali-feldspar trachyte.

Field $7^{*}$. Quartz trachyte.

Field 8*. Quartz latite.

Field 6. Alkali-feldspar trachyte.

Field 7. Trachyte.

Field 8. Latite.

Field 6'. Foid-bearing alkali-feldspar trachyte.

Field $7^{\prime}$. Foid-bearing trachyte.

Field $8^{\prime}$. Foid-bearing latite.

If fields $6^{\prime}$ to $8^{\prime}$ contain no modal foid but nepheline in the norm they may be called 'ne-normative'.

Geol. Mag. 115 (6), 1978, pp. 463-466. Printed in Great Britain. 


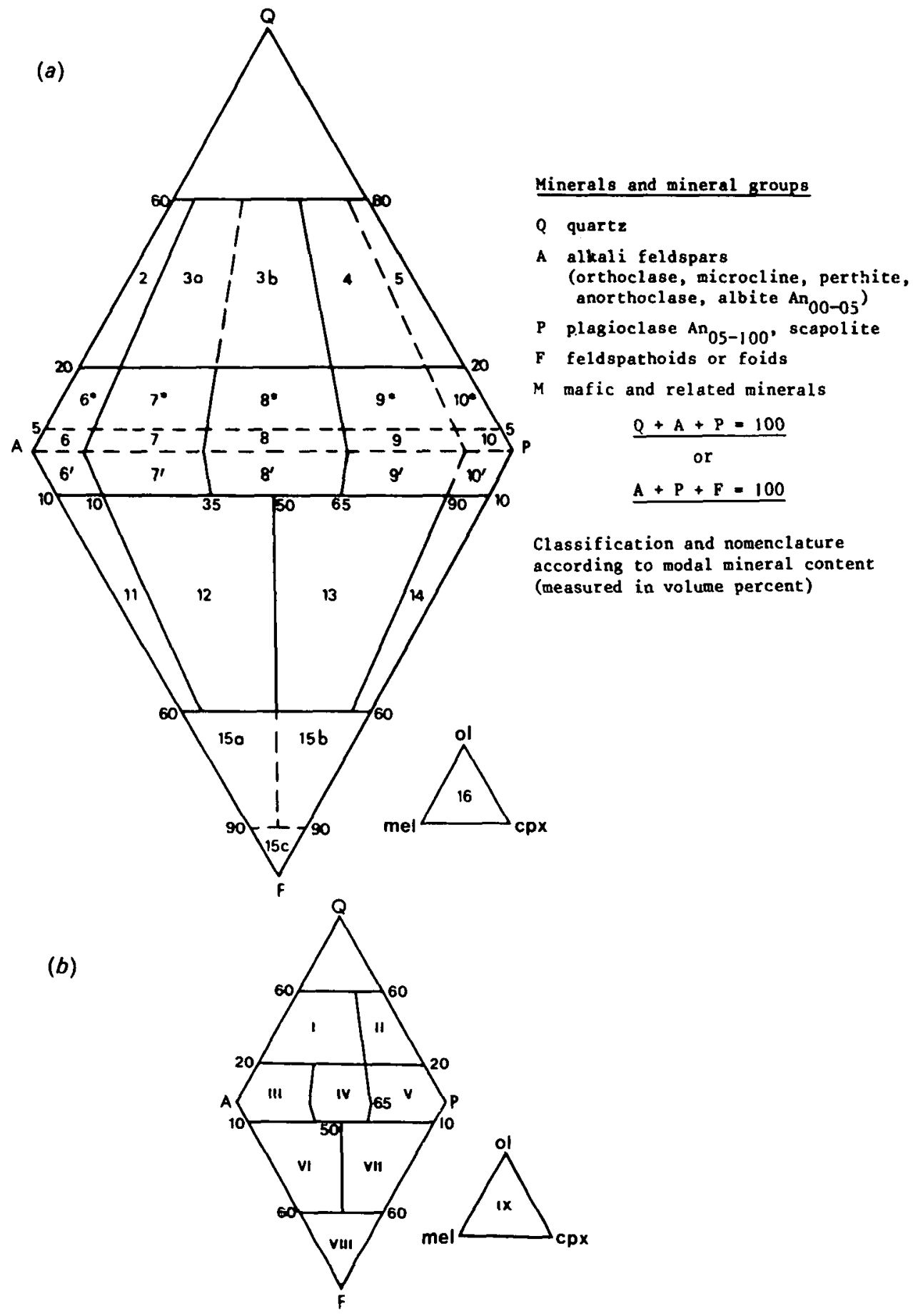

Figure 1. (a) General classification and nomenclature of volcanic rocks. Q, Quartz. A, Alkali feldspars (orthoclase, microcline, perthite, anorthoclase, albite $A n_{00-05}$ ). P, Plagioclase $A n_{05-100}$, scapolite. $F$, Feldspathoids. $Q+A+P=100$ or $F+A+P=100$. Classification and nomenclature where possible according to modal mineral content (measured in volume percentage). (b) Simplified system. 
Fields 9 and 10. Andesite and basalt. Supplementary criteria favoured for their distinction are: modal colour index ( 40 by weight, 35 by volume); $\mathrm{SiO}_{2} 52 \%$ on analysis recalculated to $100 \%$ free of $\mathrm{H}_{2} \mathrm{O}$ and $\mathrm{CO}_{2}$. The following scheme is tentatively suggested:

Colour Index

$35 \mathrm{vol} .40 \mathrm{wt}$.

Plagioclase limit of $A n_{30}$ is less satisfactory.

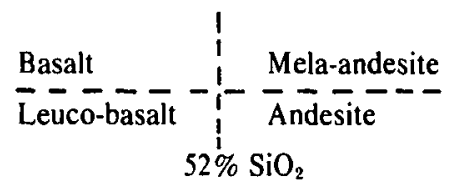

Field 11. Phonolite, i.e. with alkali-feldspar and any feldspathoid, usually with mafic minerals.

Field 12. Tephritic phonolite.

Field 13. Phonolitic tephrite; phonolitic basanite with essential olivine.

Field 14. Tephrite; basanite.

Field 15a. Phonolitic foidite (or specific feldspathoid e.g. phonolitic nephelinite).

Field 15b. Tephritic (basanitic) foidite (or specific feldspathoid distinguished).

Field 15c. Foidite (or specific feldspathoid distinguished, e.g. leucitite).

Field 16. Ultramafic effusive rocks (ultramafitites) or specific mineral distinguished, e.g. melilitite. Olivine-melilitite is preferred to melilitite-basalt. $M$ is $\geqslant o r=t o 90$.

\section{Specific usages}

Altered rocks preserving original igneous texture may be prefixed by 'meta-', e.g. meta-basalt.

'Dolerite' or 'diabase' (synonymous)

Hypabyssal rocks, usually medium-grained, of gabbroic composition which occur as minor intrusions (dykes, sills, etc.). They commonly display ophitic, subophitic or intergranular texture, and may be fresh or altered. Geological age is not involved. Similar rocks occur as the interior of thick lava flows. The use of diabase for Palaeozoic or Pre-Cambrian basalts, or for altered basalts of any geological age on the criterion only of alteration should be avoided.

\section{Melaphyre}

Discontinue use.

\section{Spilite}

Basic rocks with eruptive features (texture, fabric) and the assemblage albite-chlorite. Rich in alkalis (sodium or potassium or both) and poor in calcium. They may be of magmatic, metasomatic, or metamorphic origin.

\section{Keratophyre}

Alkali-feldspar trachyte, rich in sodium, essentially composed of albite, some microperthite, and mafic minerals (amphibole or diopsidic augite, epidote, chlorite). Frequently of metasomatic or metamorphic origin (usually enriched in sodium owing to secondary albitization of feldspar) and commonly associated with spilites. Rocks with additional quartz are termed 'quartz keratophyre'.

\section{Porphyry}

Terms such as granite-porphyry, diorite-porphyry, etc., may be used but porphyrite should be avoided.

\section{Simplified system}

In a simplified system the names may be grouped: 2, 3a, 3b I rhyolite; 4, 5 II dacite; 6,7 .III trachyte; 8 IV latite; $9,10 \mathrm{~V}$ andesite, basalt; 11,12 VI phonolite; 13 , 14 VII tephrite, basanite; 15 VIII foidites; 16 IX ultramafitites (Fig. 1 b). 
Melilitic igneous rocks

Discussion of these rocks is not completed; it is noted that melilitite is used as the group term for melilite-rich extrusive rocks, and melilitolite for the intrusive rocks.

\section{Lamprophyres}

These dyke rocks are distinguished from other plutonic and volcanic rocks by mineral and chemical composition and by texture. A conventional classification is acceptable, but discussion is not complete.

\section{Carbonatites}

These are igneous rocks, intrusive or extrusive, with more than $50 \%$ by volume of carbonate minerals. Five classes are distinguished based on the type of carbonate mineral.

Sövite

Coarse-grained light-coloured, calcite-carbonatite; $>90 \%$ of carbonate is calcite.

Alvikite

Medium- to fine-grained, light-coloured, calcite-carbonatite.

Beforsite

Dolomite-carbonatite; $>90 \%$ of carbonate is dolomite

\section{Ferrocarbonatite}

Essentially composed of iron-rich carbonates.

\section{Natrocarbonatite}

Alkali ( $\mathrm{Na}$ and $\mathrm{K}$ ) and calcium carbonates. (At present, only known from Oldoinyo Lengai volcano, N Tanzania).

\section{Melanocratic and leucocratic}

These terms should not be used for carbonatites.

Other minerals characteristically present are shown as prefixes, e.g. aegirine-sövite, etc.

\section{References}

Sabine, P. A. 1974. How should rocks be named? Geol. Mag. 111, 165-76.

Streckeisen, A. 1976. To each plutonic rock its proper name. Earth-Sci. Rev. 12, 1-33.

Institute of Geological Sciences

P. A. SABINE

Exhibition Road

London SW7 2DE

30th January 1978 